\title{
Sistem Pendukung Keputusan Seleksi Beasiswa Bantuan Belajar Mahasiswa Menggunakan Metode Modified-Simple Additive Weighting
}

\author{
Haryo Bagus Setyawan \\ Program Studi D4 Teknik Informatika Politeknik Negeri Malang \\ e-mail: haryobagus14@gmail.com \\ Diajukan: 18 Mei 2020; Direvisi: 30 Juni 2020; Diterima: 2 Oktober 2020
}

\begin{abstract}
Abstrak
Politeknik Negeri Malang merupakan sebuah Perguruan Tinggi di Kota Malang yang selalu menyalurkan bantuan dana beasiswa dari pemerintah kepada mahasiswa yang kurang mampu. Banyaknya pendaftar peserta beasiswa membuat kesulitan dalam menangani pengolahan data, sehingga diperlukan sebuah perangkat lunak untuk mempermudah pengolahan data tersebut. Penentuan kriteria penerima beasiswa ditentukan dari data yang sudah ada yaitu pendapatan orang tua, tanggungan orang tua, status orang tua, semester dan nilai Indeks Prestasi Komulatif (IPK) mahasiswa. Di dalam perangkat lunak tersebut dibuat sistem pendukung keputusan yang menggunakan metode Modified-Simple Additve Weighting di mana Simple Additive Weighting digunakan untuk pembobotan dan proses normalisasi sedangkan Weighted Product digunakan untuk memperbaiki bobot kriteria, menentukan vektor $S$ dan pemeringkatan. Sistem pendukung keputusan ini dapat menghasilkan alternatif terbaik, sehingga seleksi penerimaan calon mahasiswa penerima beasiswa dapat berjalan sesuai dengan yang diharapkan. Dari hasil perhitungan, didapatkan hasil pemeringkatan yang memiliki nilai $V$ yang paling besar yaitu VI dengan nilai 0,181 .
\end{abstract}

Kata kunci: Sistem Pendukung Keputusan, M-SAW, Beasiswa.

\begin{abstract}
Malang State Polytechnic is a University in Malang that always distributes scholarship funds from the government to underprivileged students. The large number of scholarship registrants makes it difficult to handle data processing, so we need a software to facilitate the data processing. Determination of criteria for scholarship recipients is determined from existing data, namely parental income, parental dependents, parental status, semester and cumulative grade point average (GPA) of students. In this software a decision support system is created that uses the Modified-Simple Additive Weighting method where Simple Additive Weighting is used for weighting and normalization processes while the Weighted Product is used to improve the criteria weight, determine the $S$ vector and ranking. This decision support system can produce the best alternative, so that the selection of acceptance of prospective scholarship recipients can run as expected. From the calculation results, obtained ranking results that have the greatest value of $V$, namely V1 with a value of 0,181 .
\end{abstract}

Keywords: Decision Support System, M-SAW, Scholarship.

\section{Pendahuluan}

Pada lembaga pendidikan khususnya pada Perguruan Tinggi banyak sekali beasiswa yang ditawarkan kepada mahasiswa. Ada beberapa jenis beasiswa yang ditawarkan seperti beasiswa yang berasal dari pemerintah ataupun swasta. Untuk mendapatkan beasiswa tersebut maka harus sesuai dengan kriteria yang sudah ditetapkan, seperti IPK, penghasilan orang tua, jumlah tanggungan orang tua, semester dan lainlain.

Tidak semua mahasiswa yang mendaftar beasiswa bisa mendapatkannya. Banyak hal yang membuat mahasiswa tidak mendapatkan beasiswa yang diinginkan salah satunya karena banyaknya jumlah persaingan atau pendaftar untuk beasiswa tersebut. Selain itu perhitungan masih dilakukan secara manual. Dengan menggunakan cara tersebut, pastinya membutuhkan waktu lama dan rentan terhadap kesalahan. 
Oleh karena itu diperlukannya pembuatan sistem pendukung keputusan. Dengan menggunakan sistem pendukung keputusan diharapkan dapat memudahkan pengambilan keputusan. Pada penelitian sistem pendukung keputusan penerima beasiswa sebelumnya, metode SAW diterapkan untuk membantu dalam memberikan keputusan untuk penerima beasiswa secara tepat [1]. Kelebihan dari SAW dengan proses pemeringkatan yang simple dan sederhana, dapat diterapkan untuk kasus-kasus pengambilan keputusan seperti di dalam penerima beasiswa dengan berbagai macam atribut [2]. Sistem yang akan digunakan dalam penelitian ini akan menggunakan kombinasi metode sistem pendukung keputusan antara Simple Additive Weighting (SAW) dan Weighted Product (WP), yang disebut sebagai Modified Simple Additive Weighting (M-SAW). Penggunaan WP digunakan karena bobot dihitung berdasarkan tingkat kepentingan dan dapat mengevaluasi kumpulan atribut dengan perkalian seluruh kriteria dengan hasil alternatif serta perpangkatan antara bobot dengan hasil perkalian alternatif [3]. Selain itu metode WP dapat digunakan di dalam membantu menentukan penerima beasiswa berdasarkan apa yang dibutuhkan [4]. Alasan pemilihan M-SAW adalah untuk menghasilkan keputusan penerima beasiswa yang tepat. Selain itu, penerapan metode SAW digunakan untuk perhitungan bobot dan normalisasi, di mana adanya pembagian antara nilai alternatif terhadap seluruh nilai terbesar maupun terkecil dari alternatif pada kriteria yang dituju dan metode WP digunakan untuk pembagian dari hasil total perkalian rating atribut dan menghasilkan nilai terbaik yang menjadi alternatif terbaik [5].

\section{Metode Penelitian}

Pada penelitian sebelumnya [6], sistem pendukung keputusan hanya menggunakan metode SAW. Sedangkan pada penelitian ini digunakan metode M-SAW, metode SAW yang diterapkan dapat membantu menentukan berdasarkan kriteria yang sudah ditentukan [6]. Sedangkan pada metode WP dengan adanya perbaikan bobot menghasilkan pemeringkatan yang lebih baik dan dapat memperbaiki pembobotan yang dinilai belum sempurna [7].

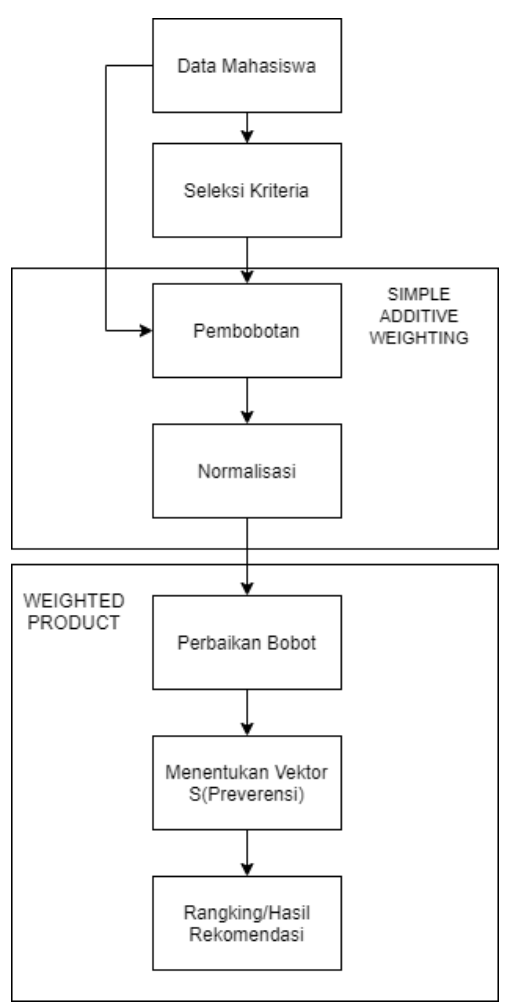

Gambar 1. Rancangan metode Modified Simple Additive Weighting (M-SAW).

Berdasarkan Gambar 1, rancangan tersebut dibagi menjadi dua bagian yaitu metode SAW dan WP. Proses tersebut dimulai dari pengumpulan data mahasiswa, kemudian melakukan seleksi kriteria sesuai dengan kriteria yang diperlukan dan melakukan pembobotan. Setelah itu hasil dari pembobotan di normalisasi, tahap pembobotan dan juga normalisasi merupakan tahap dari metode SAW. Selanjutnya untuk tahap WP dilakukan perbaikan bobot, menentukan nilai preferensi alternatif dan juga melakukan pemeringkatan atau mendapatkan hasil keputusan berdasarkan nilai terbaik. 


\subsection{Data Mahasiswa}

Data mahasiswa yang digunakan untuk perhitungan ini menggunakan data mahasiswa yang mendaftar beasiswa BBM di Politeknik Negeri Malang angkatan tahun 2015. Jumlah mahasiswa yang mendaftar program BBM adalah 332 orang. Data yang dicoba dalam melakukan perhitungan sebanyak 6 data alternatif. Cara memasukkan data ini pada aplikasi dilakukan dengan cara manual di dalam aplikasi

\subsection{Seleksi Kriteria}

Pada sistem ini menggunakan 5 kriteria yang harus dipenuhi masing-masing data alternatif, di antaranya pendapatan orang tua, tanggungan orang tua, status orang tua, semester, dan nilai Indeks Prestasi Kumulatif (IPK) mahasiswa.

\subsection{Simple Additive Weighting (SAW)}

Menurut [8], metode penjumlahan terbobot disebut metode Simple Additive Weighting. Metode ini digunakan untuk memperoleh jumlah peringkat kinerja terbobot untuk masing-masing alternatif pada semua atribut [9]. Pada metode ini diperlukan adanya proses normalisasi dari matriks (x) yang dibandingkan dengan alternatif yang ada.

$$
r_{i j}=\left[\begin{array}{l}
\frac{x_{i j}}{\operatorname{Max}_{x i j}} ; \text { merupakan atribut benefit } \\
\frac{\operatorname{Min}_{x i j}}{x_{i j}} ; \text { merupakan atribut cost }
\end{array}\right.
$$

Keterangan:

$$
\begin{array}{ll}
r_{i j} & =\text { Nilai kinerja ternormalisasi } \\
x_{i j} & =\text { Nilai normalisasi dari alternatif terhadap atribut yang berada didalam baris/kolom } \\
\operatorname{Max}_{x i j} & =\text { Nilai tertinggi dari alternatif dan atribut } \\
\operatorname{Min}_{x i j} & =\text { Nilai terendah dari alternatif dan atribut }
\end{array}
$$

Setelah dilakukan proses di atas, maka hasilnya tersebut akan digunakan ke dalam matriks ternormalisasi (r). untuk menghitung hasil pemeringkatan, dapat diperoleh dengan cara penjumlahan antara perkalian tiap bobot terhadap nilai yang ada pada matriks (r) dengan cara:

$$
V_{i}=\sum_{j=1}^{M} w_{j} r_{i j} ; i=1,2,3, \ldots, N
$$

Keterangan:

$$
\begin{array}{ll}
V_{i} & =\text { Skor akhir alternatif I (nilai terbesar merupakan nilai alternatif yang akan terpilih) } \\
w_{j} & =\text { Bobot masing-masing kriteria } \\
r_{i j} & =\text { Skor ternormalisasi untuk alternatif I pada masing-masing kriteria } \\
M & =\text { Jumlah kriteria } \\
N & =\text { Jumlah alternatif }
\end{array}
$$

\subsection{Weighted Product (WP)}

Cara pengambilan keputusan dengan perkalian untuk menghubungkan rating atribut, di mana rating setiap atribut harus dipangkatkan terlebih dahulu dengan bobot atribut yang bersangkutan disebut dengan metode Weighted Product (WP)[10]. Proses pada metode WP, memiliki tahapan yang secara umum sama dengan proses normalisasi. Pemilihan untuk setiap alternatif ditentukan dengan syarat untuk perpangkatan nilai bobot, jika pembobotan termasuk cost maka nilai pangkat dari bobot adalah negatif, dan jika pembobotan masuk dalam kategori benefit, maka nilai pangkat dari bobot adalah positif:

$$
S_{i}=\prod_{j=1}^{n} X_{i j}^{w j} ; i=1,2, \ldots, m
$$

Untuk nilai dari bobot setiap atribut (w), dilakukan proses perhitungan nilai masing-masing atribut dibagi dengan total bobot masing-masing atribut yang ada: 


$$
w_{k}=\frac{w_{j}}{\sum_{j=1}^{n} w_{j}}
$$

Kesimpulan dari rumus untuk perhitungan total adalah:

Keterangan:

$$
V_{i}=\frac{\prod_{j=1}^{n} X_{i j}^{w j}}{\prod_{j=1}^{n}\left(X_{j}\right)^{w j}} ; i=1,2, \ldots, m
$$

$S_{i}=$ Nilai preferensi alternatif, dianalogikan dengan vektor $\mathrm{S}$

$\mathrm{n} \quad=$ Banyaknya kriteria

$\mathrm{j} \quad=$ Kriteria

$\mathrm{i} \quad=$ Alternatif

$\mathrm{m}$ = Banyaknya alternatif

$\mathrm{X}=$ Skor alternatif untuk masing-masing kriteria, bernilai positif untuk benefit atribut dan negatif untuk cost atribut

$V_{i}=$ Nilai preferensi alternatif akhir, dianalogikan dengan vektor $\mathrm{V}$

$w_{j}=$ Bobot kriteria sebelum dinormalisasi

$w_{k}=$ Bobot kriteria setelah dinormalisasi

\subsection{Modified Simple Additive Weighting (M-SAW)}

M-SAW pada penelitian ini merupakan kombinasi dari metode SAW dan WP. Metode SAW digunakan untuk proses pembobotan dan normalisasi sedangkan WP digunakan untuk perbaikan bobot dan menentukan vektor s, v, serta proses pemeringkatan.

Pada penelitian ini kriteria yang digunakan berjumlah 5 atribut yang digunakan sebagai kriteria dalam menentukan penerima beasiswa. Kriteria yang digunakan yaitu:

1. Jumlah pendapatan orang tua, dengan range kurang dari Rp 1.000 .000 hingga lebih dari $\mathrm{Rp}$ 5.000.000.

2. Jumlah tanggungan orang tua, dengan range 1 anak sampai dengan lebih dari 4 anak.

3. Status orang tua, dengan pilihan lengkap, duda, janda, dan meninggal dunia.

4. Semester, dengan pilihan semester 2 sampai dengan 5 .

5. Nilai IPK mahasiswa, dengan range kurang dari 2.50 sampai dengan lebih dari 3.50 .

\section{Hasil dan Pembahasan}

Pada bagian ini akan dijelaskan mengenai hasil dari pembahasan-pembahasan topik yang telah dijelaskan di atas. Sistem ini dibuat dengan menggunakan bahasa pemrograman PHP, dengan framework CodeIgniter. Implementasi database dalam sistem ini dibuat menggunakan MySQL dengan Apache (XAMPP) sebagai localhost-nya. Sistem pendukung keputusan penerima beasiswa ini memiliki beberapa menu. Adapun tampilan menu dari hasil penelitian ini dapat dilihat pada Gambar 2 - Gambar 7:

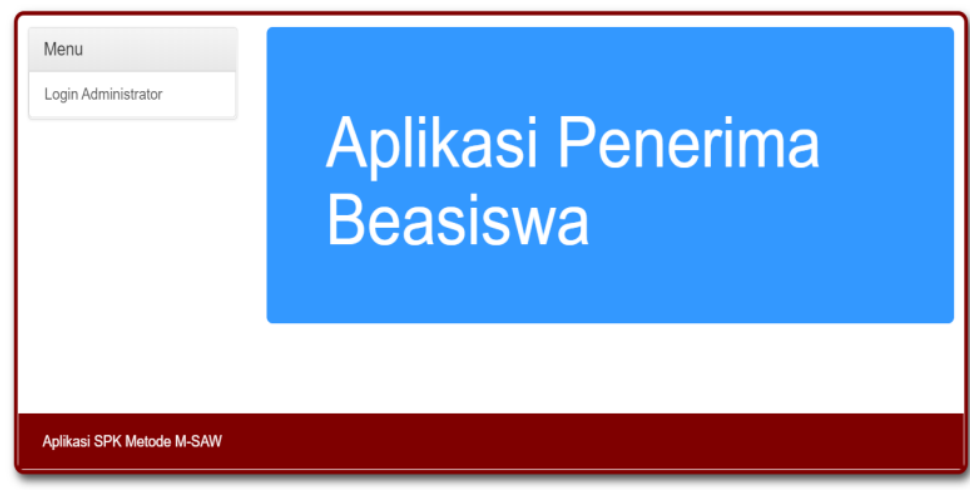

Gambar 2. Tampilan halaman utama. 


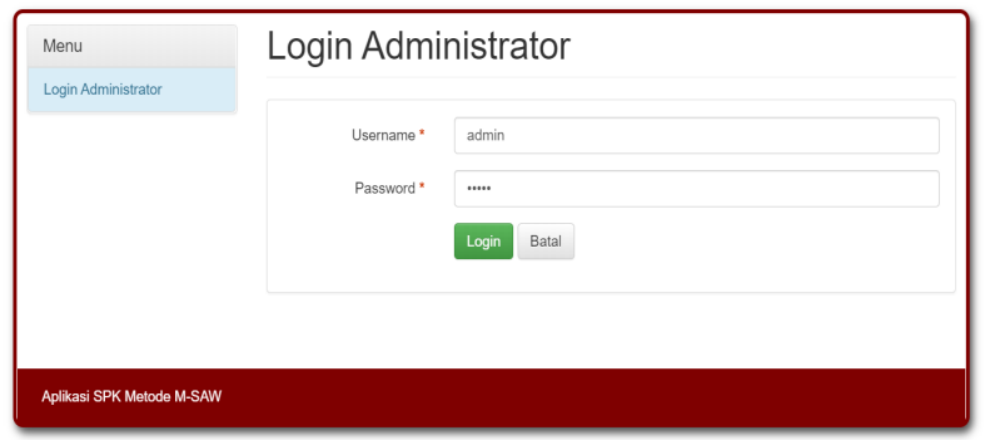

Gambar 3. Tampilan halaman Login.

\begin{tabular}{|c|c|c|c|c|c|c|}
\hline Menu User & \multicolumn{6}{|c|}{ Data Kriteria } \\
\hline W Halaman Depan & \multirow[b]{3}{*}{ NO } & \multirow[b]{3}{*}{ KODE } & \multirow[b]{3}{*}{ NAMA KRITERIA } & \multirow[b]{3}{*}{ ATRIBUT } & \multirow[b]{3}{*}{ Вовот } & \multirow{2}{*}{ Input Baru } \\
\hline 円Data Kriteria & & & & & & \\
\hline 田Data Subkriteria & & & & & & AKSI \\
\hline 由 Data Alternatif & 1 & к01 & Jumlah Pendapatan Orang Tua & Beneffit & Cukup & Eda Hapus \\
\hline 田 Hasil Seleksi & 2 & к02 & Jumlah Tanggungan Orang Tua & Beneffit & Rendah & Edit Hapus \\
\hline \multirow{3}{*}{$\leftrightarrow$ Logout } & 3 & коз & Status Orang Tua & Benefit & Sangat Rendah & Edit Hapus \\
\hline & 4 & к04 & Semester & Beneffit & Sangat Rendah & Eon Hasus \\
\hline & 5 & KO5 & IPK & Beneffit & Cukup & Edt Haous \\
\hline
\end{tabular}

Gambar 4. Tampilan halaman Data Kriteria.

\begin{tabular}{|c|c|c|c|c|}
\hline Menu User & \multicolumn{4}{|c|}{ Data Subkriteria } \\
\hline ה Halaman Depan & \multirow{2}{*}{\multicolumn{3}{|c|}{ Jumlah Pendapatan Orang Tua }} & \\
\hline 田Data Kriteria & & & & + Input Baru \\
\hline 田 Data Subkriteria & No & NAMA SUBKRITERIA & NILAI & AKSI \\
\hline 田Data Alternatif & 1 & $x>=5.000 .000$ & 0.25 & Eat Hapus \\
\hline 田Hasil Seleksi & 2 & $3.000 .000<x<5.000 .000$ & 0.5 & Edit Hapus \\
\hline$\leftrightarrow$ Logout & 3 & $1.000 .000<X<=3.000 .000$ & 0.75 & Eat Hapus \\
\hline$\rightarrow$ Logout & 4 & $X<=1.000 .000$ & 1 & Edt Hasus \\
\hline
\end{tabular}

Gambar 5. Tampilan halaman Data Subkriteria .

\begin{tabular}{|c|c|c|c|c|c|}
\hline Menu User & \multicolumn{5}{|c|}{ Data Alternatif } \\
\hline * Halaman Depan & \multirow[b]{3}{*}{ No } & \multirow[b]{3}{*}{ NAMA } & & & \multirow[b]{2}{*}{ Input Baru } \\
\hline 田Data Kriteria & & & & & \\
\hline 由Data Subkriteria & & & ALAMAT & J. KELAMIN & AKSI \\
\hline דData Alternatif & 1 & ABDUL ROZAQ & . & Laki-laki & Eor Hapus \\
\hline 田 Hasil Seleksi & 2 & ACHMAD ALWAN PUTRA PRATAMA & - & Laki-laki & Eat Hapus \\
\hline \multirow{4}{*}{$\leftrightarrow$ Logout } & 3 & INDRA YULIARTA IFA EFENDI & - & Laki-laki & Edit Hapus \\
\hline & 4 & NOVI KHICMATUL LESTARI & - & Perempuan & Edit Hapus \\
\hline & 5 & RUSDIAN HASBI RIDHO & - & Laki-laki & Eat Hapus \\
\hline & 6 & ZIDNY ALBAAR & . & Laki-laki & Edt Hapus \\
\hline
\end{tabular}

Gambar 6. Tampilan halaman Data Alternatif 


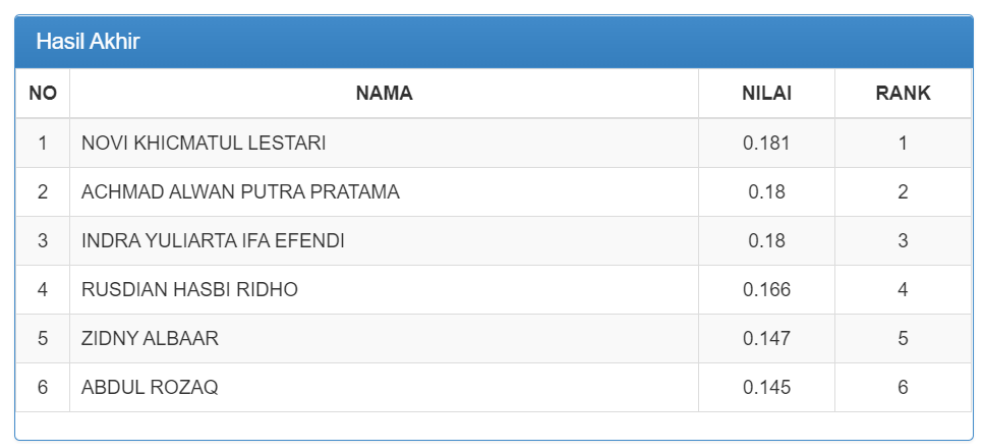

Gambar 7. Tampilan halaman Hasil Seleksi .

Gambar 2 merupakan Tampilan utama aplikasi ini. Pada halaman ini terdapat menu login administrator untuk admin, menu menu lain seperti: menu user yang memuat data kriteria, data sub kriteria, data alternatif, dan hasil seleksi. Pada Gambar 3 dapat dilihat tampilan dari halaman login untuk aplikasi sistem pendukung keputusan pemberian beasiswa ini. Di halaman ini user, admin dapat login dengan menggunakan username dan password yang sudah dimiliki .

Berdasarkan hasil observasi, maka dibuat kriteria penilaian atau bobot untuk masing-masing kriteria, dengan rincian seperti yang ditunjukkan pada Tabel 1 sampai Tabel 5. Pada tahap ini merupakan simulasi uji coba terhadap perhitungan penerimaan beasiswa. Berikut ini merupakan tabel untuk beberapa kriteria beserta nilainya yang dibuat berdasarkan data yang ada:

Tabel 1. Kriteria jumlah pendapatan orang tua.

\begin{tabular}{cc}
\hline Kriteria & Nilai \\
\hline$X>=5.000 .000$ & 0,25 \\
\hline $3.000 .000<X<5.000 .000$ & 0,5 \\
\hline $1.000 .000<X<=3.000 .000$ & 0,75 \\
\hline$X<=1.000 .000$ & 1 \\
\hline
\end{tabular}

Tabel 2. Kriteria jumlah tanggungan orang tua.

\begin{tabular}{cc}
\hline Kriteria & Nilai \\
\hline 1 anak & 0,25 \\
\hline 2 anak & 0,5 \\
\hline 3 anak & 0,75 \\
\hline$>4$ anak & 1 \\
\hline
\end{tabular}

Tabel 3. Kriteria status orang tua.

\begin{tabular}{cc}
\hline Kriteria & Nilai \\
\hline Lengkap & 0,25 \\
\hline Duda & 0,5 \\
\hline Janda & 0,75 \\
\hline Meninggal Dunia & 1 \\
\hline
\end{tabular}

Tabel 4. Kriteria semester.

\begin{tabular}{cc}
\hline Kriteria & Nilai \\
\hline Semester 2 & 0,25 \\
\hline Semester 3 & 0,5 \\
\hline Semester 4 & 0,75 \\
\hline Semester 5 & 1 \\
\hline
\end{tabular}

Tabel 5. Kriteria IPK

\begin{tabular}{cc}
\hline Kriteria & Nilai \\
\hline IPK $<2.50$ & 0,25 \\
\hline $3.50<=$ IPK $<=3.00$ & 0,5 \\
\hline $3.00<$ IPK $<=3.50$ & 0,75 \\
\hline IPK $>3.50$ & 1 \\
\hline
\end{tabular}


Berdasarkan kriteria tersebut, dilakukan simulasi untuk mengetahui hasil perhitungan dengan metode M-SAW. Untuk alternatif yang diberikan diambil sampel sebanyak 6 data untuk perhitungan, yaitu A1 = Abdul Rozaq, A2 = Achmad Alwan Putra Pratama, A3 = Indra Yuliarta Ifa Efendi, A4 = Novi Khicmatul Lestari, A5 = Rusdin Hasbi Ridho, A6 = Zidny Albaar.

Berdasarkan Tabel 1 sampai dengan 5 terdapat masing-masing parameter, dengan demikian untuk masing-masing kriteria terhadap alternatif adalah sebagai berikut:

Tabel 6. Nilai setiap alternatif kriteria (konversi).

\begin{tabular}{llcccccc}
\hline \multirow{2}{*}{ Kriteria } & \multicolumn{7}{c}{ Alternatif } \\
\cline { 3 - 8 } & $\mathbf{1}$ & $\mathbf{2}$ & $\mathbf{3}$ & $\mathbf{4}$ & $\mathbf{5}$ & $\mathbf{6}$ \\
\hline K01 & Jumlah pendapatan orang tua & 0,75 & 0,75 & 0,75 & 1 & 0,75 & 0,75 \\
\hline K02 & Jumlah tanggungan orang tua & 0,25 & 0,75 & 0,75 & 0,5 & 0,5 & 0,5 \\
\hline K03 & Status orang tua & 0,25 & 0,25 & 0,25 & 0,25 & 0,25 & 0,25 \\
\hline K04 & Semester & 1 & 1 & 1 & 1 & 1 & 1 \\
\hline K05 & IPK & 0,75 & 0,75 & 0,75 & 0,75 & 0,75 & 0,5 \\
\hline
\end{tabular}

Berdasarkan Tabel 6, akan ditentukan penilaian bobot. Pada penelitian menggunakan M-SAW ini menggunakan bobot dari penelitian sebelumnya [1].

Tabel 7. Bobot per kriteria.

\begin{tabular}{lc}
\hline \multicolumn{1}{c}{ Kriteria } & Nilai Bobot \\
\hline Jumlah pendapatan orang tua & 3 \\
\hline Jumlah tanggungan orang tua & 2 \\
\hline Status orang tua & 1 \\
\hline Semester & 1 \\
\hline IPK & 3 \\
\hline
\end{tabular}

Berdasarkan Tabel 7, diperoleh bobot dari masing-masing kriteria. Pada metode M-SAW, untuk penentuan bobot ditentukan oleh seorang pakar, yang di mana nilai bobot ditentukan oleh hasil observasi lapangan. Pembobotan berdasarkan referensi penelitian sebelumnya [6]. Dari Tabel 6 akan dilakukan normalisasi dengan metode SAW pada persamaan (1), selanjutnya melakukan perbaikan bobot dengan metode WP dengan menggunakan persamaan (4) dari Tabel 7. Kemudian menentukan vektor S dengan menggunakan persamaan (3) dan yang terakhir mencari vektor $\mathrm{V}$ menggunakan persamaan (5).

Proses normalisasi (beberapa contoh), karena seluruh kriteria benefit maka menggunakan persamaan (1) bagian atas:

$$
\begin{aligned}
& R_{1,1}=\frac{0,75}{\max (0,75 ; 0,75 ; 0,75 ; 1 ; 0,75 ; 0,75)}=\frac{0,75}{1}=0,75 \\
& R_{2,1}=\frac{0,25}{\max (0,25 ; 0,75 ; 0,75 ; 0,5 ; 0,5 ; 0,5)}=\frac{0,25}{0,75}=0,333 \\
& R_{3,1}=\frac{0,25}{\max (0,25 ; 0,25 ; 0,25 ; 0,25 ; 0,25 ; 0,25)}=\frac{0,25}{0,25}=1 \\
& R_{4,1}=\frac{1}{\max (1 ; 1 ; 1 ; 1 ; 1 ; 1)}=\frac{1}{1}=1 \\
& R_{5,1}=\frac{0,75}{\max (0,75 ; 0,75 ; 0,75 ; 0,75 ; 0,75 ; 0,5)}=\frac{0,75}{0,75}=1
\end{aligned}
$$

Hasil Normalisasi:

$$
\text { Matriks (r) }=\left[\begin{array}{cccccc}
0,75 & 0,75 & 0,75 & 1 & 0,75 & 0,75 \\
0,333 & 1 & 1 & 0,667 & 0,667 & 0,667 \\
1 & 1 & 1 & 1 & 1 & 1 \\
1 & 1 & 1 & 1 & 1 & 1 \\
1 & 1 & 1 & 1 & 1 & 0,667
\end{array}\right]
$$

Perbaikan Bobot:

$$
\begin{array}{r}
w 1=\frac{3}{3+2+1+1+3}=\frac{3}{10}=0,3 \\
w 2=\frac{2}{3+2+1+1+3}=\frac{3}{10}=0,2 \\
w 3=\frac{1}{3+2+1+1+3}=\frac{3}{10}=0,1 \\
w 4=\frac{1}{3+2+1+1+3}=\frac{3}{10}=0,1
\end{array}
$$

Sistem Pendukung Keputusan Seleksi Beasiswa Bantuan Belajar Mahasiswa Menggunakan Metode Modified-Simple Additive Weighting (Haryo Bagus Setyawan) 
Vektor S:

$$
w 5=\frac{3}{3+2+1+1+3}=\frac{3}{10}=0,3
$$

$$
\begin{aligned}
& S 1=\left(0,75^{0,3}\right) *\left(0,333^{0,2}\right) *\left(1^{0,1}\right) *\left(1^{0,1}\right) *\left(1^{0,3}\right)=0,736 \\
& S 2=\left(0,75^{0,3}\right) *\left(1^{0,2}\right) *\left(1^{0,1}\right) *\left(1^{0,1}\right) *\left(1^{0,3}\right)=0,917 \\
& S 3=\left(0,75^{0,3}\right) *\left(1^{0,2}\right) *\left(1^{0,1}\right) *\left(1^{0,1}\right) *\left(1^{0,3}\right)=0,917 \\
& S 4=\left(1^{0,3}\right) *\left(0,667^{0,2}\right) *\left(1^{0,1}\right) *\left(1^{0,1}\right) *\left(1^{0,3}\right)=0,922 \\
& S 5=\left(0,75^{0,3}\right) *\left(0,667^{0,2}\right) *\left(1^{0,1}\right) *\left(1^{0,1}\right) *\left(1^{0,3}\right)=0,845 \\
& S 6=\left(0,75^{0,3}\right) *\left(0,667^{0,2}\right) *\left(1^{0,1}\right) *\left(1^{0,1}\right) *\left(0,667^{0,3}\right)=0,748
\end{aligned}
$$

Pemeringkatan (V):

$$
\begin{aligned}
& V 1=\frac{0,736}{0,736+0,917+0,917+0,922+0,845+0,748}=0,145 \\
& V 2=\frac{0,917}{0,736+0,917+0,917+0,922+0,845+0,748}=0,18 \\
& V 3=\frac{0,917}{0,736+0,917+0,917+0,922+0,845+0,748}=0,18 \\
& V 4=\frac{0,922}{0,736+0,917+0,917+0,922+0,845+0,748}=0,181 \\
& V 5=\frac{0,845}{0,736+0,917+0,917+0,922+0,845+0,748}=0,166 \\
& V 6=\frac{0,748}{0,736+0,917+0,917+0,922+0,845+0,748}=0,147
\end{aligned}
$$

Dari hasil perhitungan di atas, didapatkan hasil pemeringkatan yang memiliki nilai V yang paling besar yaitu V1 dengan nilai 0,181, sehingga Novi Khicmatul Lestari (A4) diputuskan sebagai penerima beasiswa. Untuk hasil rekomendasi yang lebih jelas bisa dilihat pada Tabel 8. Kebaruan penelitian ini adalah sistem yang akan digunakan dalam penelitian ini akan menggunakan kombinasi metode sistem pendukung keputusan antara Simple Additive Weighting (SAW) dan Weighted Product (WP), yang disebut sebagai Modified Simple Additive Weighting (M-SAW). Sedangkan pada penelitian sebelumnya hanya menggunakan sistem SAW saja. Penambahan penggunaan WP digunakan karena bobot dihitung berdasarkan tingkat kepentingan dan dapat mengevaluasi kumpulan atribut dengan perkalian seluruh kriteria dengan hasil alternatif serta perpangkatan antara bobot dengan hasil perkalian alternatif. Selain itu metode WP dapat digunakan di dalam membantu menentukan penerima beasiswa berdasarkan apa yang dibutuhkan.

Tabel 8. Hasil akhir (pemeringkatan).

\begin{tabular}{lcc}
\hline \multicolumn{1}{c}{ Nama } & Nilai & Rank \\
\hline Novi Khicmatul Lestari & 0,181 & 1 \\
\hline Achmad Alwan Putra Pratama & 0,18 & 2 \\
\hline Indra Yuliarta Ifa Efendi & 0,18 & 3 \\
\hline Rusdian Hasbi Ridho & 0,166 & 4 \\
\hline Zidny Albaar & 0,147 & 5 \\
\hline Abdul Rozaq & 0,145 & 6 \\
\hline
\end{tabular}

\section{Kesimpulan}

Berdasarkan penelitian yang telah dilakukan, tujuan penelitian ini telah dicapai dengan baik. Dengan adanya penggunaan kombinasi metode ini telah menghasilkan rekomendasi yang tepat di dalam penentuan Beasiswa Bantuan Belajar Mahasiswa. Meskipun banyaknya persaingan dalam perolehan beasiswa, namun tidak memerlukan perhitungan manual sehingga meminimalisir pemborosan waktu dan rentan terhadap kesalahan. Pada penerapan Modified Simple Additive Weighting (M-SAW), SAW digunakan dalam proses pembobotan dan normalisasi, sedangkan WP digunakan untuk perbaikan bobot, menentukan Vektor S, Vektor V dan pemeringkatan. Hasil keputusan yang dipilih berupa nilai V terbesar dari masing-masing alternatif. Pada penelitian ini V terbesar adalah Novi Khicmatul Lestari (A4) sebagai mahasiswa penerima beasiswa berdasarkan kriteria yang telah ditentukan. Dari hasil perhitungan, didapatkan hasil pemeringkatan yang memiliki nilai $\mathrm{V}$ yang paling besar yaitu V1 dengan nilai 0,181 . Adapun kelemahan dalam penelitian ini adalah penggunaan metode WP yang hanya dapat digunakan pada proses nilai yang memiliki rentang. 
Adapun saran-saran yang diberikan sebagai bahan pertimbangan bagi pihak-pihak yang berkepentingan untuk mengembangkan lebih lanjut lagi dan menyempurnakan hasil dari penelitian ini sehingga nantinya lebih baik lagi. Saran yang peneliti berikan adalah:

1. Penelitian selanjutnya diharapkan dapat mengembangkan serta menyempurnakan kriteria yang belum ada pada sistem ini sehingga menjadi lebih canggih.

2. Selain itu bisa melakukan hasil banding dengan metode lain atau metode gabungan lain untuk diterapkan dalam sistem pendukung keputusan lainnya.

3. Diharapkan ke depannya bagi user untuk memperbaiki sistem pendukung keputusan dengan menambahkan fitur keamanan yang lebih bagus lagi.

4. Menggunakan kombinasi metode SAW dan MOORA sehingga memiliki tingkat fleksibilitas yang tinggi dan kemudahan dalam memisahkan bagian subjektif dari suatu proses evaluasi ke dalam kriteria bobot keputusan dengan beberapa atribut pengambilan keputusan.

\section{Daftar Pustaka}

[1] A. P. Wicaksono, "Sistem Rekomendasi Pemilihan Smartphone Android Dengan Dana Terbatas Menggunakan Modified Simple Additive Weighting (M-SAW)," J. Transform., vol. 17, no. 2, pp. 115-123, 2020.

[2] S. Eniyati, "Perancangan Sistem Pendukung Pengambilan Keputusan untuk Penerimaan Beasiswa dengan Metode SAW (Simple Additive Weighting)," Dinamik, vol. 16, no. 2, 2011.

[3] D. M. Khairina, D. Ivando, and S. Maharani, "Implementasi Metode Weighted Product Untuk Aplikasi Pemilihan Smartphone Android,” J. Infotel, vol. 8, no. 1, pp. 16-23, 2016.

[4] R. K. Ayu, "Komparasi metode simple additive weighting dan metode weighted product dalam sistem pendukung keputusan pemilihan perbaikan jalan." Institut Teknologi Telkom Purwokerto, 2018.

[5] B. V. Christioko, H. Indriyawati, and N. Hidayati, "Fuzzy Multi-Atribute Decision Making (Fuzzy MADM) dengan Metode SAW untuk Pemilihan Mahasiswa Berprestasi," J. Transform., vol. 14, no. 2, pp. 82-85, 2017.

[6] A. Wanto, “Analisis Penerapan Sistem Pendukung Keputusan Terhadap Seleksi Penerima Beasiswa BBM (Bantuan Belajar Mahasiswa) Pada Perguruan Tinggi Menggunakan Metode Simple Additive Weighting (SAW),” 2018.

[7] G. M. Putra and N. Irawati, “Analisis Pemilihan Handphone Rekomendasi Dengan Metode Weighted Product," in Seminar Nasional Royal (SENAR), 2018, vol. 1, no. 1, pp. 199-204.

[8] A. Mukhlasin, "Sistem Pendukung Keputusan Pemilihan Smartphone Menggunakan Metode Simple Additive Weighting (SAW) Berbasis Web," Pros. SISFOTEK, vol. 2, no. 1, pp. 46-52, 2018.

[9] Y. Malau, "Implementasi Metode Simple Additive Weighting Untuk Sistem Pendukung Keputusan Promosi Kenaikan Jabatan,” Paradigma, vol. 19, no. 1, pp. 38-45, 2017.

[10] L. Farokhah and A. Kala'lembang, "Sistem Pendukung Keputusan Pemilihan Forum Mahasiswa dengan Metode Weighted Product," J. Ilm. Teknol. Inf. Asia, vol. 11, no. 2, pp. 179-190, 2017. 